\title{
Research on franchised store chain operation based on evolutionary game theory
}

\author{
Siyuan Deng ${ }^{1, *}$ \\ ${ }^{1}$ School of Management, Shanghai University of Engineering Science, 201620 Shanghai, China
}

\begin{abstract}
Franchised store chain is the most popular business model today. The franchisor and the franchisees share the same brand, but the value of the entire brand will be degraded once one side pursues self-interests in brand management. From the perspective of franchised store chain, this paper develops an evolutionary game model between franchisor and franchisees under the assumption of bounded rationality. The strategic selection of franchisor and franchisees includes cooperation and no-cooperation. In the end, the corresponding policy recommendations are proposed in the foundation of case analysis.
\end{abstract}

\section{1 introduction}

In the franchised store chain operation, the franchisees will be paid to the franchisor in the form of a commercial contract, allowing its payment to franchise, allowing it to engage in commercial business activities. Since the 19th century, the franchise chain operation has flourished around the world with its unique advantages. At present, China's franchise chains are in the stage of rapid development, and gradually become the hotspots of social idle funds ${ }^{[1]}$. Through the business model of the franchised store chain operation, the company can expand market share in a short time, reduce human training costs, enhance the market competitiveness of enterprises; On the other hand, franchises share the franchisor's operation experience, technology and brand image. At the same time, franchises also maximize the local market potential for the franchisor ${ }^{[2]}$. At present, China has introduced a system of "Commercial Franchise Management Regulations" to constrain the two sides of the franchised store chain operation, but in the moral level, due to the information asymmetry in the franchised store chain operation, franchisor and franchisees often use its advantage information is made with the contract ${ }^{[3]}$. Especially in business management, franchisor and franchisees work together to maximize their profits. In the operation, once one party is to fade in the pursuit of private purposes $^{[4]}$, the names of the entire brand will be decking, so that the franchised store chain operation of the two sides failed. How to avoid the occurrence of moral risks in the franchised store chain operation is a key issue that promotes the scientific development of its system.

The franchised store chain operation is the most popular business model in today, and has been focused on the academic circles, and existing research is mainly discussed by the moral risks arising from the franchised store chain operation. This opportunistic behavior is two- way, when the benefits of franchisor and the franchisees are not, both sides may choose to hit the car for their own interests ${ }^{[5]}$. In order to solve the joining chain because of the moral risks caused by the information asymmetry, the relevant scholars have carried out extensive and in-depth research $^{[6]}$. To prevent franchisees from hitchhiking, franchisor need to have a systematic perspective to manage their own and franchisee's profitability and their own profitability. The existing literature is based on panel data, theoretical analysis, and discusses the impact of brand management on enterprise development, with high reference significance, but research still has deficiencies. Most research mainly analyzes the moral risk issues in the franchise chain from static angles, it is difficult to fully reflect the characteristics of complex and multi-change in the business environment in the franchised store chain operation. Based on this, franchisor disclose the evolution law of brand management in the franchised store chain operation, this paper uses the theory of evolutionary games, and the policies and recommendations of promoting my country's franchise chain operations by establishing the game model of the franchisor and the franchisees.

\section{The Analysis of Evolutionary game}

\subsection{Game main body and behavioral strategy analysis}

Assuming in the "natural" environment, the model consists of a franchisor and a plurality of franchisees. Each game is randomly selected from the franchisees to pair, on this basis, research on the evolutionary game model. franchisor and the franchisees difficult to make optimal choices in a decision due to the characteristics of

\footnotetext{
* Corresponding author: E-mail address: Swain_dengsiyuan@163.com
} 
complexity, variability and information asymmetry of the two operating environment. Both sides are in long-term cooperation, all of which are limited, will start from the interests of the company, and choose the most conducive to the development of the company. At the same time, in the dynamic changes, the franchisor and the franchisees continue to adjust and improve their strategies until the evolution is stable. Franchisees and franchisor have two strategies of "cooperation" and " no-cooperation " for business strategies. The game process of the franchised store chain operation can be divided into three stages. In the first phase, the franchisor selects cooperation or nocooperation strategy according to its own needs; the second phase, the franchisee making a strategy for their own development based on the strategy of the franchisor; the third stage, the franchisor according to the franchisee's strategy, adjust Self-strategy choice. And in the three stages of the franchisor and the franchisee are limited.

\subsection{Model assumptions and related parameters setting}

H1: If a franchisor and franchisee have a no-cooperation strategy, the franchisor and the franchisees have only gain basic benefits. It assuming that $V_{1}$ and $V_{2}$, where $V_{i}>$ $0(i=1,2)$.

$\mathrm{H} 2$ : franchisor and franchisee take "cooperation", the cost investment in business activities is $C_{i}(i=1,2)$. When adopting a "cooperation" strategy, the franchisee and franchisees produce a certain market positive external effect, the greater the investment in business activities, the greater the level of consumer trust and preference, the more active.

H3: When the franchisor and franchisee take the "cooperation" strategy, the operational investment will return in a certain material form and the spiritual form. Assume that the substances obtained by the franchisor and franchisee are $E_{i}(i=1,2)$ and $E_{i}>V_{i}$. At the same time, the honorary impact of franchisor and franchisee is $I_{i}$.

H4: Suppose one party selects a "cooperation" policy, the other party selects "no-cooperation" policy, "free rider" can get additional benefits $R_{i}(i=1,2)$.

\subsection{Evolutionary game model}

Based on the above assumptions, in the operation perspective, the income of the games in both parties is analyzed, and the following franchise chain operates the game gain matrix, as Table 1 shown.

Further assuming that the probability of the "cooperation" strategy is $x, y$. The probability of " no-cooperation" strategy is $1-x$ and $1-y$.

For franchisor, when choosing different strategies, its income is also different, and its expectation earnings are:

$$
\begin{gathered}
U_{x 1}=y\left(E_{1}+I_{1}-C_{1}\right)+(1-y)\left(V_{1}+I_{1}-C_{1}\right) \\
U_{x 2}=y\left(V_{1}+R_{1}\right)+(1-y) V_{1}
\end{gathered}
$$

$$
\overline{U_{x}}=x U_{x 1}+(1-x) U_{x 2}
$$

\begin{tabular}{|c|c|c|c|}
\hline & & \multicolumn{2}{|c|}{ franchisee } \\
\hline & & cooperation & $\begin{array}{c}\text { no- } \\
\text { cooperation }\end{array}$ \\
\hline & cooperation & $\begin{array}{l}E_{1}+I_{1}-C_{1} \\
E_{2}+I_{2}-C_{2}\end{array}$ & $\begin{array}{c}V_{1}+I_{1}-C_{1} \\
\quad V_{2}+R_{2}\end{array}$ \\
\hline franchisor & $\begin{array}{c}\text { no- } \\
\text { cooperation }\end{array}$ & $\begin{array}{c}V_{1}+R_{1} \\
V_{2}+I_{2}-C_{2}\end{array}$ & $\begin{array}{l}V_{1} \\
V_{2}\end{array}$ \\
\hline
\end{tabular}

Table 1. Income matrix

For franchisee, the expectations of "cooperation" and " no-cooperation" strategy are selected, $U_{y 1}, U_{y 2}$ and the average income $\overline{U_{y}}$ are:

$$
\begin{gathered}
U_{y 1}=x\left(E_{2}+I_{2}-C_{2}\right)+(1-x)\left(V_{2}+I_{2}-C_{2}\right) \\
U_{y 2}=x\left(V_{2}+R_{2}\right)+(1-x) V_{2} \\
\overline{U_{y}}=y U_{y 1}+(1-y) U_{y 2}
\end{gathered}
$$

According to the evolutionary game replication dynamic formula, the replication dynamic equation that can be obtained by the "cooperation" strategy is:

$$
\begin{aligned}
X & =\frac{d x}{d t}=x\left(U_{x 1}-\overline{U_{x}}\right)=x(1-x)\left(U_{x 1}-U_{x 2}\right) \\
& =x(1-x)\left[y\left(E_{1}-V_{1}-R_{1}\right)+I_{1}-C_{1}\right]
\end{aligned}
$$

Similarly, the replication dynamic equation for the franchisee adopting the brand " cooperation " strategy is:

$$
\begin{aligned}
Y & =\frac{d y}{d t}=y\left(U_{y 1}-\overline{U_{y}}\right)=y(1-y)\left(U_{y 1}-U_{y 2}\right) \\
& =y(1-y)\left[x\left(E_{2}-V_{2}-R_{2}\right)+I_{2}-C_{2}\right]
\end{aligned}
$$

\subsection{Balance stability analysis}

Depending on the method of Kandori[ ${ }^{[7]}$, the evolutionary balanced stability can be obtained by analyzing local stability of the matrix of the system, and the $\mathrm{X}$ and $\mathrm{Y}$ function resolve $X$ and $Y, X$ and $Y$, to obtain the Jacobi matrix $J$ :

$$
\begin{gathered}
J=\left[\begin{array}{l}
\frac{\partial X}{\partial x} \frac{\partial X}{\partial y} \\
\frac{\partial Y}{\partial x} \frac{\partial Y}{\partial y}
\end{array}\right]=\left[\begin{array}{l}
a_{11} a_{12} \\
a_{21} a_{22}
\end{array}\right] \\
a_{11}=(1-2 x)\left[y\left(E_{1}-V_{1}-R_{1}\right)+I_{1}-C_{1}\right] \\
a_{12}=x(1-x)\left(E_{1}-V_{1}-R_{1}\right) \\
a_{21}=y(1-y)\left(E_{2}-V_{2}-R_{2}\right) \\
a_{22}=(1-2 y)\left[x\left(E_{2}-V_{2}-R_{2}\right)+I_{2}-C_{2}\right]
\end{gathered}
$$

Solving the stability point of the replication dynamic equation is the premise of obtaining the model of the model evolutionary stability, and the stability point of the replication dynamic equation is $x^{*}$ and $y^{*}$ first to satisfy $f\left(x^{*}\right)=f\left(y^{*}\right)$ Condition, if the following conditions are Satisfy: $\quad(1) \operatorname{tr}(J)=a_{11}+a_{22}<0 \quad, \quad$ (2) $\operatorname{det}(J)=$

The average expectant benefits are: 
$\left[\begin{array}{l}a_{11} a_{12} \\ a_{21} a_{22}\end{array}\right]=a_{11} a_{22}-a_{12} a_{21}>0$. The balance point of the replication dynamic equation is stable and is evolving stability strategy (ESS). From this, $\mathrm{O}(0,0), \mathrm{K}(0,1), \mathrm{L}(1$, $0), M(1,1)$ and $\mathrm{N}\left(\mathrm{x}^{*}, \mathrm{y}^{*}\right)$ five equilibrium points can be obtained, where $x^{*}=\frac{C_{2}-I_{2}}{E_{2}-V_{2}-R_{2}}, y^{*}=\frac{C_{1}-I_{1}}{E_{1}-V_{1}-R_{1}}$.

On the basis of the above analysis, the Jacobi matrix stabilization analysis method is used to analyze five equilibrium points in the game process, and the results are shown in Table 2.

Table 2. Stability analysis table

\begin{tabular}{|c|c|c|c|}
\hline $\begin{array}{c}\text { Equilibrium } \\
\text { point }\end{array}$ & DetJ & $\operatorname{TrJ}$ & Result \\
\hline $\mathrm{O}(0,0)$ & + & + & ESS \\
\hline $\mathrm{K}(0,1)$ & + & - & Unstable \\
\hline $\mathrm{L}(1,0)$ & + & - & Unstable \\
\hline $\mathrm{M}(1,1)$ & + & + & ESS \\
\hline $\mathrm{N}\left(\mathrm{x}^{*}, \mathrm{y}^{*}\right)$ & - & 0 & Saddle point \\
\hline
\end{tabular}

As can be seen from Table 2, only two points in five equilibrium points satisfy the conditions of evolutionary stability strategy, and achieve the evolutionary stability strategy, which is $\mathrm{O}(0,0)$ and $\mathrm{M}(1,1)$, respectively. The strategy of the franchisor and the franchisee selection is (cooperation, cooperation) and (cooperation, cooperation). The specific phase diagram is shown in Figure 1.

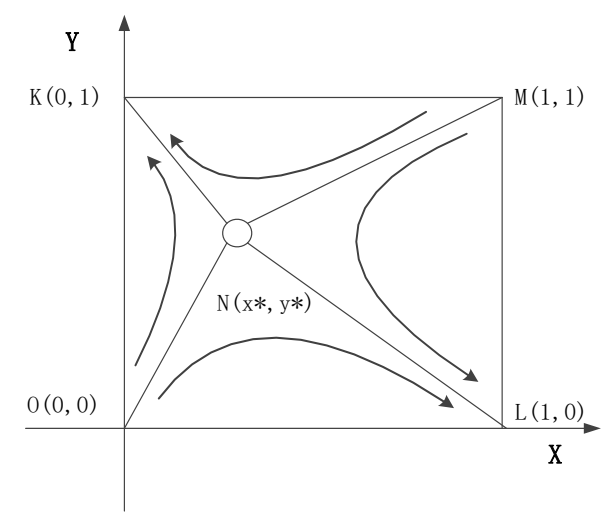

Fig. 1. Phase diagram

\section{Case discussion}

In recent years, the franchised store chain operation has become a popular project of today's social investment. There are some successful practical cases in China, combined with the research theme of this article, select the case of Beijing Tongrentang Chinese Medicine Company to actively brand management, and provide active brand management for more chain brands. Aspects of experience.

As the most famous old-fashioned old name in my country, Tongrentang Chinese Medicine is founded in 1669.Through good business management, the company's scale continues to grow. During the new crown pneumonia, Tong Ren Tang passed the Ministry of Foreign Ministry to the overseas housing and international students donated 79,000 medicines. At the same time, franchisees are also doing their efforts to do their strength for active brand management. Hong Kong retail employees have recommended their own drugs for each customer during the epidemic, which is patiently explained to the customer. It is generally how to support the health and facing the sudden condition. As long as the customer needs, whenever and where to do it, it is necessary to pursue the whole force. It is this persistence, grasping the emotions of consumers, enhances the brand value. In addition, franchisor also has a rational brand extension. According to the national quality standards, franchisor has opened up 7 Chinese herbal medicine planting bases, and the joint venture with Hunan Boxing Entrepreneurship Co., Ltd. is established. Tong Ren Tang improved the control of value chain links such as raw materials and product development in different ways, making it competitive in the upstream of the value chain. It is because of the cooperation between Tongrentang's franchisor and franchisees, making its brand's value is recognized by the public, and successfully entered the national non-material cultural heritage list, which has become China's most famous Chinese herbal medicine enterprise.

\section{Conclusions and Suggestions}

Based on the evolutionary game model of franchisor and franchisees, this paper studies the operation strategies of franchisor and franchisees as the main body of franchised store chain. Both (cooperation, cooperation) and (non cooperation, non cooperation) strategy may be the best equilibrium point, but which point the system converges to depends on the value of income matrix and specific parameters. Based on this, we put forward some suggestions:

(1) The supervision of franchisee control should be further strengthened, the design and clear joining contract, clearly state the rights and obligations of franchisor and franchisees. Franchisor should give certain substance rewards on high-quality franchisees and give a part of the high-quality development resources to performance franchisees. At the same time, the spiritual reward should be awarded with material rewards, and award high-quality franchisees awarded excellent franchisees and excellent employees, and it is also a must for its efforts to franchise.

(2) With the coming of the Internet, the current reputation publicity produces significant limitations, and brand publicity needs to be played by advertising. Use advertising to grasp the emotions of consumers. advertising is an important way to franchised store chain operation.

(3) Franchisor and the franchisees are consistent with the expectations of the customer experience by deploying the brand value in the behavior of the franchisees store employees, thus obtaining good brand rights and interests. 


\section{References}

1. Yakimova, R., Owens, M., \& Freeman, S. (2021). The 'visible hand'behind cooperation in franchising: A model of franchisor practices that influence cooperation within social networks. Industrial Marketing Management, 94, 66-89.

2. Moon, H., Ham, S., Kim, S. C., \& Lee, B. Y. (2021). Influential factors for successful knowledge transfer in restaurant franchises. Journal of Hospitality and Tourism Management, 46, 224-232.

3. Bertrand, J. L., Brusset, X., \& Chabot, M. (2021). Protecting franchise chains against weather risk: A design science approach. Journal of Business Research, 125, 187-200.

4. Kim, T. T. (2021). When Franchisee Service Affects Demand: An Application to the Car Radiator Market and Resale Price Maintenance. Marketing Science, 40(1), 101-121.

5. Lafontaine, F. (1992). Agency theory and franchising: some empirical results. The rand journal of economics, 263-283.

6. Hsu, L. T. J., \& Jang, S. S. (2008). Advertising expenditure, intangible value and risk: A study of restaurant companies. International Journal of Hospitality Management, 27(2), 259-267.

7. Kandori, M. (1997). Evolutionary game theory in economics. Advances in economics and econometrics: theory and applications, 1, 243-277. 